\title{
Analyzing High Efficiency Asynchronous Motors Using Scalar Control Technique
}

\author{
H.Uzun, O.Akar, A.Demirci, M.C.Akuner, and U.K. Terzi
}

\begin{abstract}
In industry, more than half of the total electrical energy produced in developed countries is converted into mechanical energy by electric motors. The usage rate of asynchronous motors is estimated to be $90 \%$ of all electric motors. For these motors, an improvement in efficiency may result in huge savings. These electric motors which have minimized losses can be improved with speed control drives to be more efficient in terms of energy consumption and performance. In speed control drives of asynchronous motors widely used in industry; scalar, vector control and direct torque control are used.

In this study, in a Matlab/Simulink environment, high efficiency and standard asynchronous motors with the same characteristics were driven with scalar control technique and the simulations were compared in detail. From the point of view of both speed control performance and energy saving, it observed that high efficiency motors have more advantages.
\end{abstract}

Index Terms-Asynchronous motor, High Efficiency Motors, Speed Control, Scalar Control.

\section{INTRODUCTION}

$\mathrm{W}$ ORLD industrial production mostly relies on electric motors and electric motors are performing the work of billions of people. Therefore, it is of great importance that the electric motor is highly efficient. Efficiency improvements can provide big savings. By minimizing the losses in the motor, the obtained high-efficiency motors, can not only prevent heat loss, but also minimizes any other losses. Other big advantages of high efficiency motors are that when used with variable speed drive they have advanced control characteristic [1-4].

H. UZUN, is with Department of Electrical and Electronic Technologies, Yenidoğan Vocational and Technical Anatolian High School, 34791, Istanbul, Turkey, (e-mail: hasanuzun2@hotmail.com)

O. AKAR, is with Department of Mechatronic Program, Gedik Vocational High School Istanbul Gedik University, 34700, Istanbul, Turkey, (e-mail: onur.akar@gedik.edu.tr)

A. DEMIRCI, is with Department of Electrical Engineering, Yıldı Technical University, 34220, Istanbul, Turkey, (e-mail: ademirci@yildiz.edu.tr)

M. C. AKUNER, is with Department of Mechatronic Engineering, Marmara University, 34722, Istanbul, Turkey, (e-mail: akuner@marmara.edu.tr) (iD)

U. K. TERZI, is with Department of Electrical and Electronics Engineering, Technology Faculty, Marmara University, 34722, Istanbul, Turkey, (e-mail: terzi@marmara.edu.tr) (iD

Manuscript received September 13, 2017; accepted January 08, 2018. DOI: 10.17694/bajece.410219

\section{HIGH EFFICIENCY ASYNCHRONOUS MOTORS}

It is known that the industry is the biggest electricity consuming sector in a country. In the industry of advanced countries three-quarters of the energy consumed is used in electric motors. Efficiency improvements in these motors can provide big savings.

In the production phase electric motors are generally manufactured in three classes. These classes are named according to European standards as High Efficiency Motor Class (EFF1), Standard Efficiency Motor Class (EFF2) and Low Efficiency Motor Class (EFF3). Nowadays EFF3 class motors, totally or partially disappeared from production and EFF1 and EFF2 have been used mostly in industry. In our study, subjects will be motors of these two classes.

Two different Technologies are used in the manufacture of high efficiency motors. Extending the length of the packet motor sheet is raising efficiency, and the other design is made by using higher quality sheet metal and copper. In addition, motors with rotors produced with copper injection technique do also step forward as new generation high- efficiency motors. Also in this type of motor the fan structure is designed specifically to provide better cooling. Thus the heat losses to the energy are minimized.

An electric motor cannot convert the entire energy it draws from the network which it's connected into mechanical energy. The useful power from the electric motor shaft; losses from the power drawn from the mains power out of the state. Energy losses in the motor during operation of the engine are converted into heat energy. The high efficiency motors gained from minimization of these losses, not only prevents heat loss, but also minimizes any other losses [1-11].

\section{SCALAR CONTROLS}

Due to the ease of implementation, scalar control nowadays is the best known and most widely used method of speed control for variable speed motor drives. The essential feature of this method; at speeds from zero to the rated value is that the voltage applied to the stator frequency (V / F) ratio, and thus the flux and induced torque is kept constant. At speeds above the rated speed, the increase in frequency and the voltage is kept constant; therefore, the attenuation of the flux through the rate control can be performed. Asynchronous Motor (ASM) speed drive systems using scalar methods of control have a good variable dynamic steady-state performance, but the dynamic response is not good answered. Oscillations in the air flow 
range worsens dynamic response and causes electromagnetic torque oscillation. In high-performance drive systems, oscillations in torque and speed are not required. In this type of application, high accuracy, fast position and speed control is required. If the flux and torque are controlled separately, these problems can be overcome. A method of controlling the flux and torque individually is called the vector control (field oriented control) [6, 12-18].

\section{STUdIES}

In this section, studies performed in the MATLAB/ Simulink environment are described. In the simulation study performed with MATLAB/Simulink blocks asynchronous motors with scalar control methods have been proposed. For the realization of these simulations of both efficiency classes of the Gamak motor brand and tag information of the motor equivalent circuit parameters were utilized. In Table 1 and Table 2, the tag information and equivalent circuit parameters of the motor are given.

TABLE I

HIGH EFFICIENCY MOTOR INFORMATION (EFF1 YIELD CLASS)

\begin{tabular}{|c|c|c|c|c|c|c|c|}
\hline \multicolumn{7}{|c|}{ Motor Nameplate Value } \\
\hline & Voltage & $\begin{array}{c}\text { Frequenc } \\
\mathrm{y}\end{array}$ & Current & Power & $\cos \varphi$ & Rotation & $\mathrm{J}\left(\mathrm{kgm}^{2}\right)$ \\
\hline triangle & $220 / 240 \mathrm{~V}$ & $50 \mathrm{~Hz}$ & $\begin{array}{c}4.04 / 4.01 \\
\text { A }\end{array}$ & $1.1 \mathrm{~kW}$ & 0.82 & $2900 \mathrm{~d} / \mathrm{d}$ & 0.00066 \\
\hline star & $380 / 415 \mathrm{~V}$ & $50 \mathrm{~Hz}$ & $\begin{array}{c}2.34 / 2.32 \\
\text { A }\end{array}$ & $1.1 \mathrm{~kW}$ & 0.82 & $2900 \mathrm{~d} / \mathrm{d}$ & 0.00066 \\
\hline \multicolumn{7}{|c|}{ Equivalent Circuit Parameters } \\
\hline$R 2$ & $R 2$ & $L 2$ & \multicolumn{2}{|c|}{$L 2$} & \\
\hline $10.5 \Omega$ & $0.2294 \Omega$ & $33.7 \mathrm{mH}$ & $33.7 \mathrm{mH}$ & $0.627 \mathrm{H}$ \\
\hline
\end{tabular}

TABLE II

STANDARD MOTOR INFORMATION (EFF2 YIELD CLASS)

\begin{tabular}{|c|c|c|c|c|c|c|c|}
\hline \multicolumn{7}{|c|}{ Motor Nameplate Value } \\
\hline & Voltage & $\begin{array}{c}\text { Frequenc } \\
\mathrm{v}\end{array}$ & Current & Power & $\cos \varphi$ & Rotation & $\mathrm{J}\left(\mathrm{kgm}^{2}\right)$ \\
\hline triangle & $220 \mathrm{~V}$ & $50 \mathrm{~Hz}$ & $4.4 \mathrm{~A}$ & $1.1 \mathrm{~kW}$ & 0.83 & $2800 \mathrm{~d} / \mathrm{d}$ & 0.00066 \\
\hline star & $380 \mathrm{~V}$ & $50 \mathrm{~Hz}$ & $4.4 \mathrm{~A}$ & $1.1 \mathrm{~kW}$ & 0.83 & $2800 \mathrm{~d} / \mathrm{d}$ & 0.00066 \\
\hline \multicolumn{7}{|c|}{ Equivalent Circuit Parameters } \\
\hline$R 2$ & $R 2$ & $L 2$ & \multicolumn{2}{|c|}{$L 2$} & \\
\hline $13.4 \Omega$ & $0.4834 \Omega$ & $40.3 \mathrm{mH}$ & $40.3 \mathrm{mH}$ & $0.51 \mathrm{H}$ \\
\hline
\end{tabular}

For scalar control experiment, the block diagram given in Figure 1 is used. After entering the motor tag information and equivalent circuit parameters from Table 1 and Table 2 and entering appropriate settings, the stator current and rotor speed graphics were obtained from the screen.

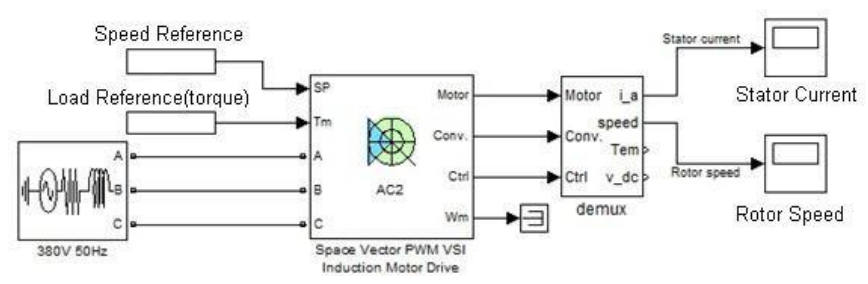

Fig.1. Scalar Control Block Diagram

In order to measure the response of asynchronous motor during loading, the motor speed reference of $3000 \mathrm{rpm}$ including $0-1 \mathrm{sec}$ in the range of load (ie. $0 \mathrm{Nm}$ ) and 1-2 sec in the range of nominal motor torque with $3.7 \mathrm{Nm}$ load reference has been entered. In Figure 2, It can be seen that the current drawn of EFF1 efficient motor at the very beginning is higher than the current drawn by the EFF2 motor. In Figure 3, EFF1 efficient motor $1 \mathrm{sec}$ at $3.7 \mathrm{Nm}$ loads the implementation of the reduction by reference speed of the rotor speed is less than EFF2 efficient motor.

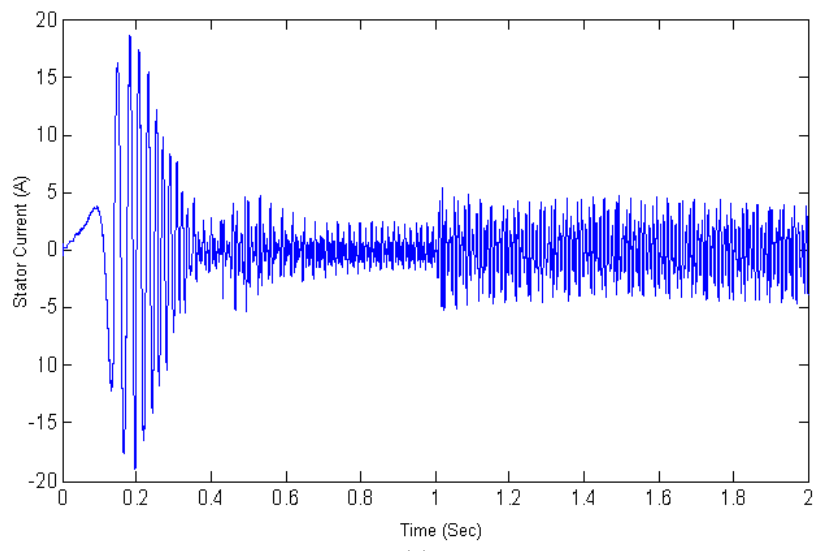

(a)

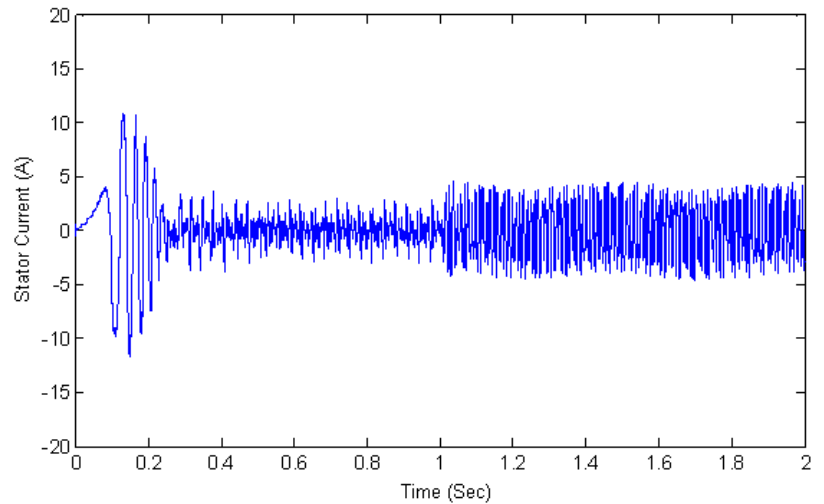

(b)

Fig.2. Scale Control in The Idle and 3.7 Nm Load Current in The Stator a) EFF1 Motor b) EFF2 Motor 


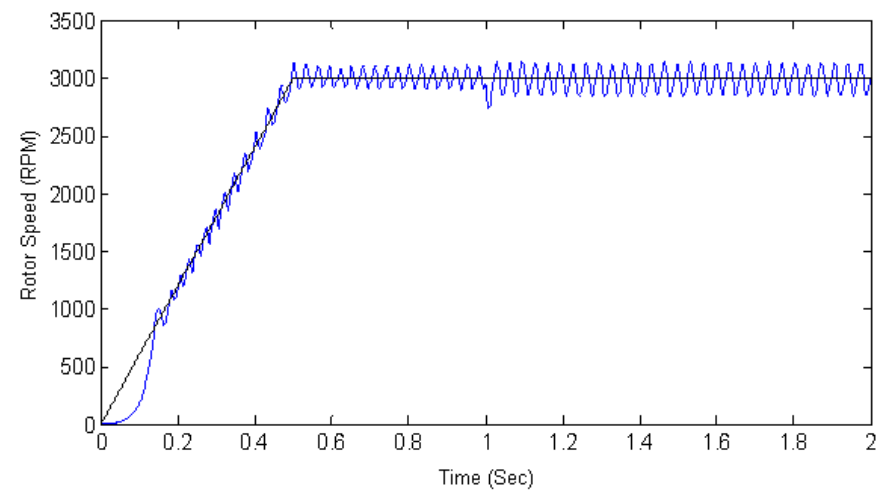

(a)

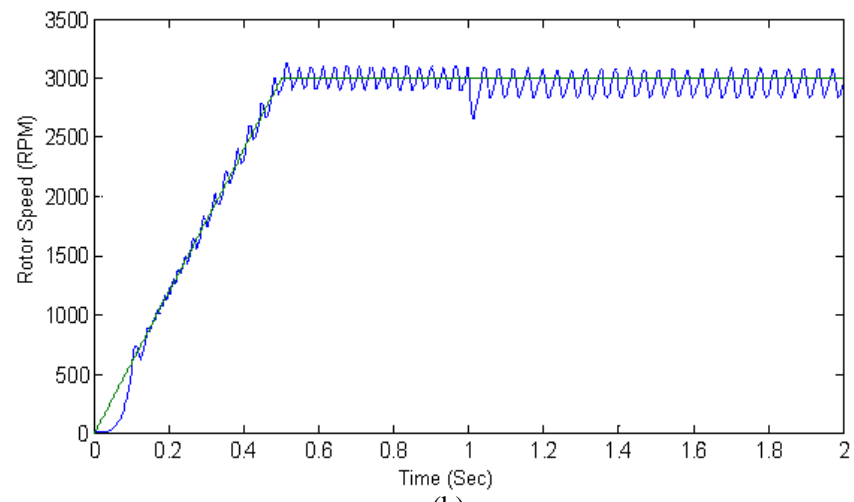

(b)

Fig.3. In The Idle and 3.7 Nm Load Variation of Rotor Speed for Scale Control a) EFF1 Motor b) EFF2 Motor

To monitor the response of the asynchronous motor against variable speed references, under no load conditions, speed references; $2000 \mathrm{rpm}$ for duration of $0-1 \mathrm{sec}, 3000 \mathrm{rpm}$ for duration of 1-2 sec, $3500 \mathrm{rpm}$ for duration of 2-3 sec, $2500 \mathrm{rpm}$ for duration of 3-4 sec and $1000 \mathrm{rpm}$ for duration of 4-5 sec were applied to motors. Figure 4 shows that at the start up stage, EFF1 motors with no load draw more current than the efficient EFF2 motor. In Figure 5, the responses of EFF1 and EFF2 efficient motors to variable speed references are seen. It can be seen that fluctuations of high efficiency motor while reaching to reference speed are less than those in the standard motor.

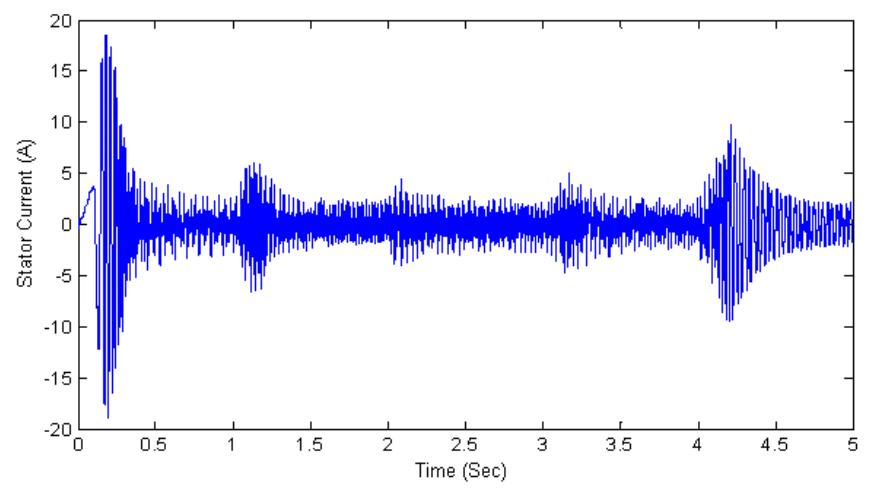

(a)

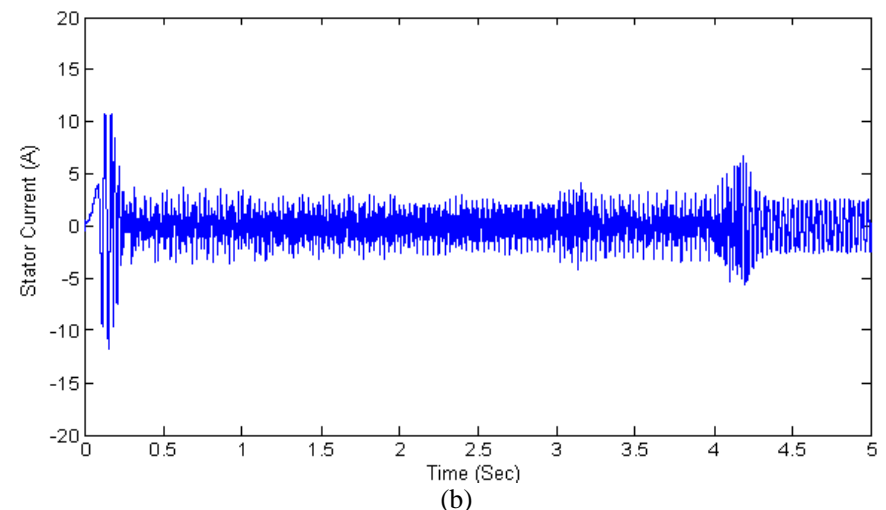

Fig.4. Stator Current Changes in The Mixed Speed Reference for Scale Control a) EFF1 Motor b) For EFF2 Motor

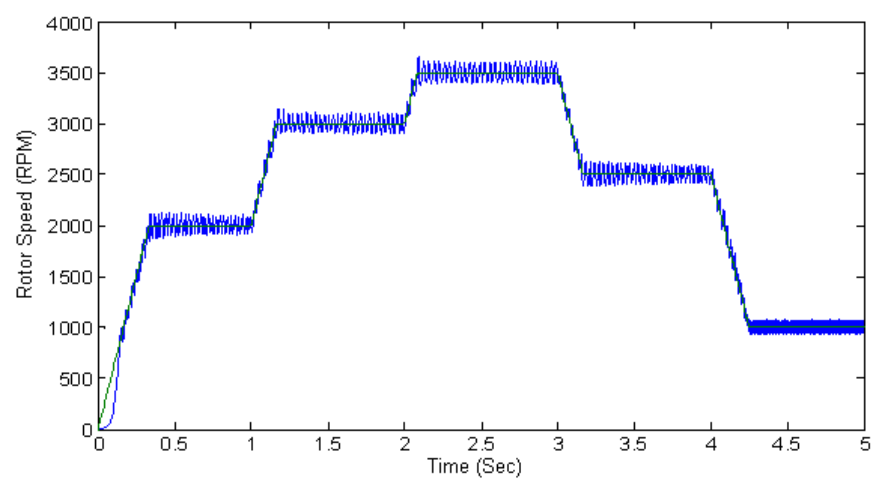

(a)

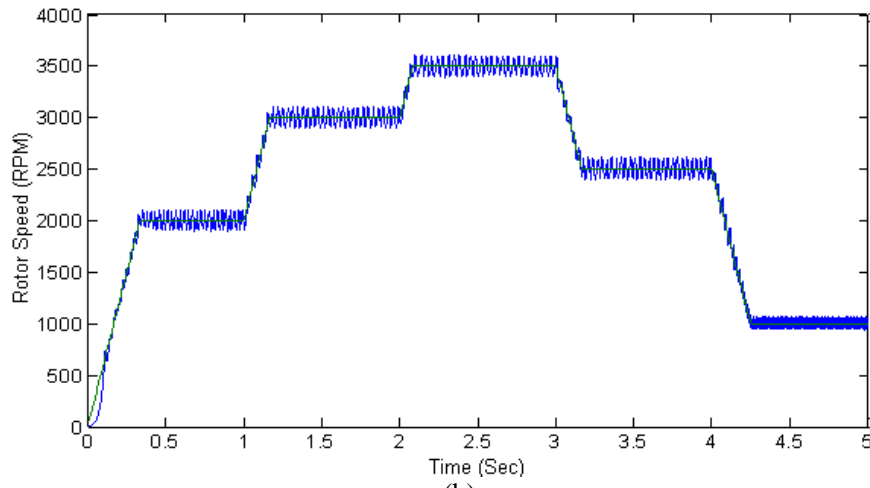

(b)

Fig.5. Variations of rotor speed in The Mixed Speed Reference for Scale Control a) For Eff1 Motor b) For EFF2 Motor

\section{CONCLUSION}

Performed in this paper, a study was done on the standard motors and highly efficient asynchronous motors which have same characteristics (power, voltage, speed) and their stator currents and speeds were compared. In the simulation study done, it is observed that the starting current in the EFF1 efficient motor is higher than the starting current of the EFF2 efficient motor. This shows that the highly efficient motor start-up torque is higher. It is also observed that the current of the efficient motor, after getting the steady state, is lower. This means that less energy is spend in continuous operation. On the other hand, it is seen that EFF1 efficient motor response to changes in motor speed is faster than the EFF2 efficient motor and fluctuations were less. This also shows that speed control characteristic in highly efficient motors is better. Generally, this study shows that high efficiency asynchronous motors are 
superior to standard motors in terms of energy saving and speed controlling characteristic. However, because the starting current in the EFF1 efficient motor is higher than the starting current of the EFF2 efficient motor, this situation causes using more sensitive protection devices.

\section{REFERENCES}

[1] H. Uzun, "Yüksek Verimli ve Standart Asenkron Motorların Farklı Hız Kontrol Yöntemleri Kullanılarak Karşılaştırılması", Master Thesis, Marmara University, Istanbul, Turkey, 2013.

[2] H. Uzun, M. C. Aküner, İ. Temiz, \& E. Hüner, (2012). "Comparison of high efficiency and standard induction motors with different speed control methods", Energy Education Science and Technology Part A Energy Science and Research. Say1 SI-1. Cilt 30 sf 533-538

[3] C. Tekin, "Yuksek Verimli Asenkron Motorların Analizi" Master Thesis, Marmara University, Istanbul, Turkey, 2008 [in Turkish].

[4] F. Akova, "Elektrik Motor Sistemlerinde Enerji Verimliligine Bakis. Verimli Endustriyel Komponentler Ic ve Dis Tic Ltd Sti" [Online]. Available: www.uevf.com.tr/uevf1/sunumlar/ot08-05.doc. [Accessed: August 16, 2011]. [in Turkish].

[5] E. Goren, "Elektrik Motoru ve Hiz Kontrol Sistemleri ile Enerji Verimliligi. Siemens San ve Tic AS" [Online]. Available: www.uevf.com.tr/uevf1/sunumlar/ot08-01.doc, [Accesses: August 16, 2011] [in Turkish].

[6] MK .SariogIu, M . Gokasan, S. Bogosyarı, "Asenkron Makinalar ve Kontrolu”, Birsen Print House, Istanbul, 2003 [in Turkish].

[7] B. Widell, D. Danfoss, L. Park, "High Efficiency Motors And Nuisance Starting Trips", Illinois, USA, 2007.

[8] J. Pyrhonen, J. Haataja, K. Luostarinen, "High Efficient Induction Motors", Lappeenranta University of Technology.

[9] [Online].Available:www.energysc.org/energy_tips.html high_efficiency_MOTORS.PDF, [ACCESSES: AUGUST 10, 2011].

[10] ABB. ACS 800 Programlama Kilavuzu [in Turkish].

[11] S. Dursun, "Energy utilization and energy efficiency", Ener Educ Sci Tech 2005; 15:59-70.

[12] N. Ozturk, "Yumusak Anahtarlamalı Asenkron Motorun Dolaylı Vektor Denetiminin Gerceklestirilmesi", PhD Thesis, Gazi University, Ankara, Turkey, 2006.

[13] A. Saygin, "Asenkron Motor Hiz Kontrolunun Matris Konverter ile Hizinin Denetlenmesi", PhD. Thesis, Gazi University, Ankara, Turkey, 2004 [in Turkish].

[14] OA. Karaman, "Dogrudan Moment Kontrollu Motor Surucu Sisteminin Incelenmesi", Master Thesis, Firat University Elazig, Turkey, 2010 [in Turkish].

[15] MK. SariogIu, M. Gokasan, S. Bogosyari, "Asenkron Makinalar ve Kontrolu", Birsen Print House, Istanbul, 2003 [in Turkish].

[16] A. Boglietti, A. Cavagnino, M. Lazzari, M. Pastorelli, "International Standards for the Induction Motor Efficiency Evaluation: A Critical Analysis of the Stray-Load Loss Determination", 2003.

[17] J. Lepka, P. Stekl, "3-Phase AC Induction Motor Vector Control Using a 56F80x, 56F8100 or 56F8300 Device. Design of Motor Control Application", 2005.

[18] A. Hazzab, M. Rahli, B. Kamli, B. Mazari, "Direct Field-Oriented Control Design using Backstepping Technique for Induction Motor Speed Control", University of Sciences and Technology of Oran, Algeria, 2009.

\section{BIOGRAPHIES}

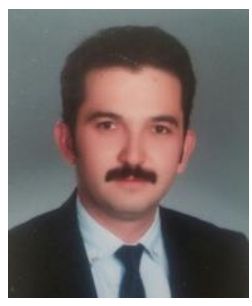

Hasan UZUN was born in Istanbul in 1986. He received his B.S. degree from Electrical Education Department of Technical Education Faculty of University of Gazi, Ankara, in 2008 and his M.Sc. degree from Electrical Education Department of Institute of Pure and Applied Sciences, University of Marmara, İstanbul, in 2013. From 2011 to 2012, he was a Lecturer in Istanbul Gedik University. Since 2012, he has been a Technical Teacher with the electrical and electronic department, Istanbul, Vocational and Technical High School. He is the author of 1 article. His research interests include power electronic, speed control of electrical motors, energy efficiency.

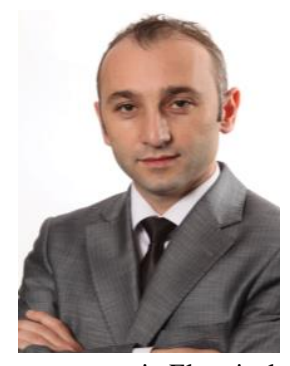

Onur AKAR was born in Giresun in 1981. He received his B.S. degree from Electrical Education Department of Technical Education Faculty of University of Marmara, Istanbul, in 2005 and his M.Sc. degree from Electrical Education Department of Institute of Pure and Applied Sciences, University of Marmara, Istanbul, in 2011. He also received B.S degree from Electrical and Electronics Engineering Department of Engineering Faculty of Karadeniz Technical University, Trabzon, in 2017. $\mathrm{He}$ has been currently attending doctorate programme in Electrical and Electronics Engineering department of Institute of Pure and Applied Sciences of Marmara University, Istanbul.

He has been working as a Lecturer at Mechatronics Program of Vocational High School of Istanbul Gedik University since 2010. He served as the Head of Electrical Department of Vocational High School of Gedik University in Istanbul between 2012 and 2015. He is the author of 2 article and one book chapter. His research interests include Control Systems, Renewable Energy Systems and Power Systems.

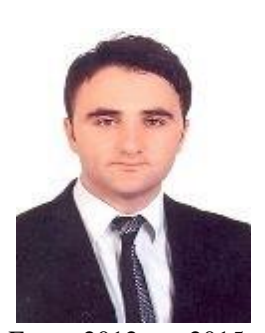

Alpaslan DEMIRCI was born in Istanbul in 1985. He received his B.S. degree from Electrical Education Department of Technical Education Faculty of University of Marmara, Istanbul, in 2007 and his M.Sc. degree from Electrical Education Department of Institute of Pure and Applied Sciences, University of Marmara, İstanbul, in 2011. He also received B.S degree from Electrical and Electronics Engineering Department of Engineering Faculty of Sakarya University, Sakarya, in 2017.

From 2012 to 2015, He was a Lecturer with the Electricity and Energy Department, İstanbul Yıldız Technical University, Vocational and High School. Since 2016, He has been a Lecturer with the Electrical Engineering Department, Istanbul Yıldız Technical University. His research interests include Power electronics, Energy Transmission and Distribution, Renewable Energy Systems.

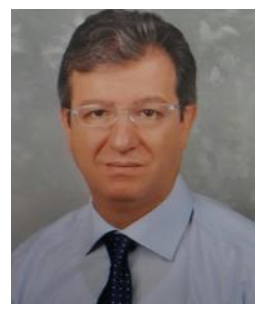

M. Caner AKUNER was born in Samsun in 1968. He received his B.S. degree from Electrical Education Department of Technical Education Faculty of University of Marmara, Istanbul, in 1990 and his M.Sc. and Ph.D. degree from Electrical Education Department of Institute of Pure and Applied Sciences, University of Marmara, Istanbul, in 1993 and 1999 respectively.

From 1990 to 1996, he worked as a research assistant, from 1993 to 1999 as a lecturer, from 1999 to 2012 as an Assistant Prof. Dr. for university of Marmara. Since 2012 he has been working as an Associate Prof. Dr. for Mechatronics Department of Technology Faculty of Marmara University.

His research interests include Electrical Machinery, Power Systems, Energy Transmission and Distribution, Renewable Energy Systems.

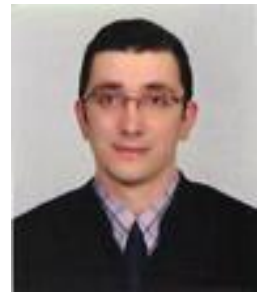

Umit K. TERZI was born in Zonguldak in 1968. He received his B.S. degree from Electrical Education Department of Technical Education Faculty of University of Marmara, Istanbul, in 1989 and his M.Sc. and Ph.D. degree from Electrical Education Department of Institute of Pure and Applied Sciences, University of Marmara, Istanbul, in 1994 and 2000 respectively.

From 1989 to 1996, he worked as a research assistant, from 1996 to 2000 as a lecturer, from 2000 to 2013 as an Assistant Prof. Dr. for university of Marmara. Since 2013 he has been working as an Associate Prof. Dr. for Electrical and Electronics department of Technology Faculty of Marmara University and Electrical Education Department of Technical Education Faculty where he is head of department.

His research interests include Electrical Machinery, Power Systems, Energy Transmission and Distribution, Renewable Energy Systems. 